\title{
Grass and Legume Hays for Sheep: Intake, in vivo Digestibility, and in situ Degradability
}

\author{
Iana Mara Medeiros Otoni \\ Departamento de Zootecnia, Universidade Federal de Viçosa \\ Avenida Peter Henry Rolfs, Campus Viçosa, 36570-900, Viçosa, Brazil. \\ E-mail: ianamotoni@yahoo.com.br
}

Janaina Lima da Silva

Centro Multidisciplinar de Barra, Universidade Federal do Oeste da Bahia Avenida 23 de Agosto, Assunção, 47100-000, Barra, Brazil

Tel: +51-74-999867557_E-mail: janaina.lima@ufob.edu.br

Karina Guimarães Ribeiro (Corresponding Author)

Departamento de Zootecnia, Universidade Federal de Viçosa

Avenida Peter Henry Rolfs, Campus Viçosa, 36570-900, Viçosa, Brazil

Tel: +51-31-994784909Ｅ-mail: karinaribeiro@ufv.br

Odilon Gomes Pereira

Departamento de Zootecnia, Universidade Federal de Viçosa Avenida Peter Henry Rolfs, Campus Viçosa, 36570-900, Viçosa, Brazil Tel: +51-31-991203396_E-mail: odilon@ufv.br

Thiago Carvalho da Silva

Departamento de Zootecnia, Universidade Federal Rural da Amazonia Avenida Presidente Tancredo Neves, 2501, Bairro Terra Firme, 66.077-830, Belém, Brazil. E-mail: timao22@hotmail.com 
Alltech do Brazil

Avenida Advogado Horácio Raccanello Filho, 4660 - Sala 1705 - Zona 10, 87030-405,

Maringá, Brazil. E-mail: Ifsilva@alltech.com

Sebastião de Campos Valadares Filho

Departamento de Zootecnia, Universidade Federal de Viçosa

Avenida Peter Henry Rolfs, Campus Viçosa, 36570-900, Viçosa, Brazil

Tel: +51-31-997644524Ｅ-mail: scvfilho@ufv.br

Received: May 1, 2021 Accepted: May 31, $2021 \quad$ Published: June 15, 2021

doi:10.5296/jas.v9i3.18588

URL: https://doi.org/10.5296/jas.v9i3.18588

\begin{abstract}
The objective of this study was to evaluate nutrient intake, in vivo digestibility, and in situ degradability of different cultivars of hay (i.e., [Jiggs] and [Tifton-85] bermuda grass (Cynodon spp.) and [alfalfa] (Medicago sativa) and [stylo] Campo Grande (Stylosanthes sp.)) and nitrogen balance in sheep. We used eight rumen-cannulated F1 Santa Ines $\times$ Dorper castrated male sheep with body weights of $35.0 \mathrm{~kg}$ in a double $4 \times 4$ Latin Square experimental design. The intake and total apparent digestibility of nutrients were higher $(\mathrm{P}<0.05)$ for alfalfa than for stylo hay. The in vivo dry matter (DM) digestibility of Jiggs (47.6\%), Tifton-85 (53.4\%), stylo (29.3\%), and alfalfa (53.2\%) hays and in situ DM degradability were equivalent in the range of 7.6 to $63.2 \mathrm{~h}$ of degradation. The in vivo neutral detergent fiber (NDFap) digestibility of Jiggs (53.7\%), Tifton-85 (64.4\%), stylo (42.2\%), alfalfa (56.2\%), and in situ NDFap degradability were equivalent from $37.3 \mathrm{~h}$. Nitrogen balance was negative only in animals fed stylo hay. Alfalfa hay provides a higher nutrient intake than other hays. The alfalfa and bermuda grass hays used in sheep diets presented better digestibility than stylo hay. The results are suitable to predict in vivo digestibility from in situ degradability parameters.
\end{abstract}

Keywords: alfalfa, jiggs, stylo, tifton-85

\title{
1. Introduction
}

The optimal utilization of diets by ruminants is influenced by the chemical composition and physical characteristics of the feed (Kammes et al., 2012). According to Kammes and Allen (2012), the passage of digesta from the rumen is a dynamic process that is affected by numerous feed and animal factors. These authors observed that when using alfalfa silage or orchard grass silage as the only source of forage, the selective retention of small particles was less for legumes than for grass, resulting in lower rumen fill and less effective fiber. 
To validate a particular feed in relation to meeting the nutritional requirements of the animals, in vivo digestibility tests have been performed. According to Olivo et al. (2017), techniques such as in vivo tests are the most accurate methods for determining the nutritional value of feeds used in animal diets, but they are more expensive. Thus, alternative methods, such as in situ degradability tests, have been used in several studies in the field of animal nutrition (Chaudhry \& Mohamed, 2011; Krizsan et al., 2013; Benninghoff et al., 2015) to evaluate the kinetics of ruminal degradation of several feeds used in diets.

According to Di Marco et al. (2009), the ability of in situ and in vitro methodologies to accurately predict in vivo data depends on the incubation period, which is variable between feeds, suggesting that caution should be exercised when using these techniques to estimate the digestibility of different feeds during fixed periods of incubation. Chaudhry and Mohamed (2011) verified that the in situ method was suitable for identifying differences in dry matter $(\mathrm{DM})$ and crude protein $(\mathrm{CP})$ degradation among different feeds.

The substitution of in vivo digestibility analysis for in situ degradability analysis is relevant in the study of ruminant diets because it decreases costs. Therefore, we aimed to compare nutrient intake, in vivo digestibility, and in situ degradability of grasses (Cynodon cv. Jiggs and Tifton-85) and legumes (Medicago sativa and Stylosanthes Campo Grande) hays, and the nitrogen balance of sheep.

\section{Method}

The experiment was conducted at the Department of Animal Science of Federal University of Viçosa, Viçosa, Minas Gerais, Brazil. Animal management and care were carried out according to the norms and recommendations of the Ethical Committee on the Use of Production Animals/CEUAP/UFV, protocol n. 030/2015.

\subsection{Experimental Diets}

The experimental diets consisted of alfalfa hay (Medicago sativa), Campo Grande stylo hay $(S$. capitata $\times S$. macrocephala), Tifton-85 hay (Cynodon spp.), and Jiggs hay (Cynodon dactylon) as exclusive feed sources (Table 1). In addition, the animals received fresh water and mineral supplement ad libitum. The mineral supplement was offered separately from the hay, and its formula was as follows: copper sulfate (16.77\%), zinc sulfate $(81.20 \%)$, cobalt sulfate $(0.77 \%)$, potassium iodate $(0.62 \%)$, and sodium selenite $(0.64 \%)$.

Table 1. Chemical composition of hays used in experimental diets $\left(\mathrm{g} \mathrm{kg}^{-1} \mathrm{DM}\right)$

\begin{tabular}{lllllllllll}
\hline Hay & DM & OM & CP & EE & NDFap & NFC & ADF & iADF & iNDF & LIG \\
\hline Jiggs & 850 & 918 & 138 & 30.0 & 598 & 136 & 318 & 5.00 & 311 & 35.0 \\
Tifton-85 & 894 & 925 & 106 & 27.0 & 656 & 175 & 329 & 4.00 & 276 & 31.0 \\
Stylo & 866 & 935 & 63.0 & 18.0 & 679 & 152 & 512 & 4.70 & 445 & 94.0 \\
Alfalfa & 868 & 905 & 83.0 & 27.0 & 538 & 257 & 383 & 3.90 & 301 & 62.0 \\
\hline
\end{tabular}

$D M$, dry matter; $O M$, organic matter; $C P$, crude protein; $E E$, ether extract; NDFap, neutral detergent fiber corrected for ash and protein; $N F C$, non-fiber carbohydrates; $A D F$, acid detergent fiber; $i A D F$, indigestible acid detergent fiber; $i N D F$, indigestible neutral detergent fiber; $L I G$, lignin. 


\subsection{Animal and Management}

For this study, eight crossbred Santa Inês $\times$ Dorper castrated male sheep with an average body weight of $35 \mathrm{~kg}$ cannulated in the rumen were used. The animals were distributed in individual metabolic cages, in two $4 \times 4$ Latin squares containing four treatments, four animals, and four experimental periods each one. At the beginning of the adaptation period, the animals were dewormed and weighed. Weighing was also performed at the end of each experimental period, which lasted for 17 days, with 10 days for adaptation of the animals to the diets and seven days for sample collection. The diets were offered to the animals twice per day, half at 08:00 $\mathrm{h}$ and half at 15:00 h, allowing approximately $15 \%$ leftovers due to the high selectivity of sheep.

\subsection{Intake, Fecal Collection, and Degradability Trial}

Intake was estimated from the 11th to the 13th days of each experimental period by weighing the feed offered and the leftovers in the $24 \mathrm{~h}$ period. During the same period, total fecal collection was performed using bags to determine total apparent digestibility.

For the incubations in the in situ degradability test, hay samples $(5 \mathrm{~g})$ were weighed and placed in $15 \times 8 \mathrm{~cm}$ nylon bags corresponding to each treatment and incubation period $(0,3$, $6,12,24,36,48,72$, and $96 \mathrm{~h}$ ), following the procedure described by Mehrez and Ørskov (1977).

\subsection{Chemical Analysis}

Feed, leftovers, and feces samples collected during the experimental period and the in situ incubation residues were used to determine $\mathrm{DM}$, organic matter $(\mathrm{OM}), \mathrm{CP}$, ether extract, and neutral detergent fiber corrected for ash and protein (NDFap), according to the methodologies described by Detmann et al. (2012). The equations proposed by Sniffen et al. (1992), Hall et al. (1999), and Weiss et al. (1992) for the estimation of total carbohydrates, non-fibrous carbohydrates, and total digestible nutrients (TDN) were used. To determine the indigestible neutral detergent fiber (iNDF), samples from the four hays were ground to $2 \mathrm{~mm}$ and incubated in the rumen of two sheep using Ankom ${ }^{\circledR}$ bags (filter bags F57) for a 288-h period (Valente et al., 2011).

\subsection{Statistical Analysis}

Nutrient intake and digestibility were evaluated using PROC MIXED Statistical Analysis System, version 9.2, considering animal and experimental periods as random effects and the Latin square as a fixed effect. Averages were compared using the following orthogonal contrasts: I - legume hay versus grass hay, II - Jiggs hay versus Tifton-85 hay; and III Campo Grande stylo hay versus alfalfa hay.

The in situ degradation rates of DM and OM were calculated using the equation described by Ørskov \& McDonald (1979): $\mathrm{D}(\%)=\mathrm{a}+\mathrm{b}\left(1-\mathrm{e}^{-\mathrm{ct}}\right)$ where $\mathrm{D}$ represents the degradability, or the disappearance of the nutrient feed; $a$ is the fraction of water-soluble feed at time zero; $b$ is the fraction insoluble in water, but potentially degradable; $\mathrm{c}$ is the rate of degradation of the potentially degradable fraction (b); and $\mathrm{t}$ is the incubation time (h). The in situ degradation of 
NDF (Y) was estimated according to the decreasing exponential model proposed by Mertens \& Loften (1980): $\mathrm{Y}=\mathrm{b} \times \mathrm{e}-\mathrm{k}(\mathrm{t}-\mathrm{L})+\mathrm{I}$, where $\mathrm{Y}$ is the residue remaining at time $\mathrm{t}, \mathrm{b}$ is the potentially digestible fraction, $\mathrm{k}$ is the digestion rate constant, $\mathrm{t}$ is the incubation time, $\mathrm{L}$ is the discrete lag time, and I is the indigestible fraction of the fiber. For the non-linear adjustments related to the equations described above and the determination of the parameters, the iterative Gauss-Newton algorithm implemented in the PROC NLIN of the SAS was used. The effective degradability (ED) of DM and OM of hays was calculated using the following model: $\mathrm{DE}=\mathrm{a}+((\mathrm{b} \times \mathrm{kd})) /(\mathrm{kd}+\mathrm{kp})$. The ED of NDF of the hays was calculated using the following model: $\mathrm{DE}=\left(\left(\mathrm{B} \times \mathrm{kd} \times \mathrm{e}^{\wedge}(-\mathrm{kp} \times \mathrm{L})\right)\right) /(\mathrm{kd}+\mathrm{kp})$, where $\mathrm{kp}$ corresponds to the rate of passage of the particles in the rumen. In this study, $2 \% \mathrm{~h}^{-1} \mathrm{kp}$ was used because of the exclusive intake of roughage by the animals in the in vivo test.

The results of the in vivo digestibility of DM, OM, and NDF were compared with the in situ degradability assay at different incubation times. From the confidence interval calculated for in vivo digestibility, the times at which the lower and upper limits of the range were the same as the in situ degradability were obtained, which is indicated as a suggestion of schedules in which the in situ degradability estimates the in vivo digestibility and can replace it. The in situ degradation of DM, OM, and NDF was analyzed using the NLIN procedure with the Marquardt algorithm. For all comparisons, the 5\% level was established as a critical level to test the probability of a type I error.

\section{Results}

\subsection{Intake and Total Apparent Digestibility Of Nutrients}

Nutrient intake was higher $(\mathrm{P}<0.05)$ in animals fed alfalfa hay than in those fed stylo hay (Table 2). The total apparent digestibility of all nutrients was higher $(\mathrm{P}<0.05)$ for alfalfa hay than for style hay. Alfalfa hay provided a higher $\mathrm{BN}$ content $(\mathrm{P}<0.05)$ than stylo hay (Table 2).

Table 2. Nutrient intake and total apparent digestibility in sheep fed grass and legume hays

\begin{tabular}{|c|c|c|c|c|c|c|c|c|}
\hline \multirow{2}{*}{ Item } & \multicolumn{4}{|c|}{ Hay } & \multirow{2}{*}{ SEM } & \multicolumn{3}{|c|}{ Contrast ( $P$ value $)$} \\
\hline & Jiggs & Tifton-85 & Stylo & Alfalfa & & I & II & III \\
\hline \multicolumn{9}{|l|}{ Intake $\left(\right.$ g day $\left.^{-1}\right)$} \\
\hline Dry matter & 797 & 788 & 555 & 1116 & 96.7 & 0.670 & 0.954 & 0.002 \\
\hline Organic matter & 734 & 736 & 518 & 1014 & 87.5 & 0.736 & 0.990 & 0.002 \\
\hline Crude protein & 110 & 79.3 & 37.4 & 97.2 & 8.80 & 0.011 & 0.035 & 0.001 \\
\hline Ether extract & 28.5 & 24.8 & 12.4 & 35.8 & 2.70 & 0.352 & 0.365 & $<0.001$ \\
\hline NDFap & 481 & 536 & 372 & 600 & 56.6 & 0.706 & 0.521 & 0.016 \\
\hline iNDF & 216 & 184 & 213 & 244 & 20.4 & 0.094 & 0.172 & 0.170 \\
\hline Non-fiber carbohydrates & 118 & 87.6 & 102 & 296 & 33.0 & 0.006 & 0.481 & $<0.001$ \\
\hline iNDF/NDFap & 35.6 & 46.3 & 57.7 & 43.9 & 4.03 & 0.029 & 0.087 & 0.028 \\
\hline Digestible organic matter & 385 & 431 & 193 & 616 & 71.9 & 0.964 & 0.677 & 0.002 \\
\hline Nitrogen Balance $\left(\mathrm{g} \mathrm{day}^{-1}\right)$ & 4.71 & 1.80 & -0.87 & 6.96 & 1.04 & 0.846 & 0.080 & 0.000 \\
\hline
\end{tabular}

Intake $\left(\mathrm{g} \mathrm{kg}^{-1}\right.$ of live weight) 
Dry matter

Organic matter

NDFap

iNDF
23.0

21.2

14.0

6.20

\section{1}

20.6

15.0

5.10

Total Apparent Digestibility $\left(\mathrm{g} \mathrm{kg}^{-1}\right)$

Dry matter

Organic matter

Crude protein

NDFap

Non-fiber carbohydrates

$515 \quad 581$

$702 \quad 637$

$537 \quad 644$

$236 \quad 286$

$476 \quad 534$

$\begin{array}{lll}16.0 & 31.5 & 3.00\end{array}$

0.701

0.765

$\begin{array}{ll}0.828 & 0.003\end{array}$

$14.9 \quad 28.7$

2.70

1.80

0.717

0.871

0.004

10.7

6.10

6.80

0.50

0.099

0.027

0.101

0.255

Stylo, Stylo Campo Grande; SEM, standard error of the mean; NDFap, neutral detergent fiber corrected for ash and protein; iNDF, indigestible neutral detergent fiber; I, legume hay vs. grass hay; II, jiggs hay vs. Tifton-85 hay; III, Stylo hay vs. Alfalfa hay.

\subsection{In Vivo Digestibility and in Situ Degradability}

For Jiggs, Tifton-85 and stylo hays, the in vivo DM digestibility (47.6, 53.4, and 29.4\%) was equivalent to that obtained by the in situ method, in the range of 15.9 to $51.9 \mathrm{~h}$ degradation (Table 3, Figure 1a), 22.4 to $63.2 \mathrm{~h}$ of degradation (Figure $1 \mathrm{~b}$ ), and 7.65 to $25.4 \mathrm{~h}$ of degradation (Figure 1c), respectively. For alfalfa hay, the in vivo DM digestibility of $53.3 \%$ can be compared to the in situ method, in the range of 13.8 to $42.6 \mathrm{~h}$ of degradation (Figure 1d). When in situ DM degradability was compared, the range of 22.4-25.4 h was common for all hays. However, when comparing the Jiggs, Tifton-85, and alfalfa hay values, the comparison interval was higher, ranging from 22.4 to $42.6 \mathrm{~h}$.

Table 3. In situ degradability and in vivo digestibility in sheep fed different grass and legume hay

\begin{tabular}{|c|c|c|c|c|c|c|c|c|c|c|c|c|}
\hline \multirow[t]{2}{*}{ Hay } & \multicolumn{5}{|c|}{ In situ Degradability } & \multirow[t]{2}{*}{ ED } & \multicolumn{3}{|c|}{$\begin{array}{l}\text { In vivo } \\
\text { Digestibility }\end{array}$} & \multicolumn{2}{|c|}{$\begin{array}{l}\text { Incubation } \\
\text { (h) }\end{array}$} & \multirow{2}{*}{$\begin{array}{l}\text { time } \\
\text { UL }\end{array}$} \\
\hline & $\mathrm{a}$ & $\mathrm{b}$ & $K \mathrm{~d}$ & $\mathrm{I}$ & lag & & $\mathrm{LL}$ & Mean & UL & $\mathrm{LL}$ & Mean & \\
\hline \multicolumn{13}{|c|}{ Dry matter } \\
\hline Jiggs & 9.406 & 48.384 & 0.061 & _- & - & 36.034 & 39.4 & 47.6 & 55.8 & 15.9 & 25.5 & 51.9 \\
\hline Tifton-85 & 6.097 & 58.929 & 0.048 & - & - & 34.836 & 44.7 & 53.4 & 62.1 & - & - & - \\
\hline Stylo & 6.894 & 39.407 & 0.059 & - & _ & 28.225 & 21.2 & 29.4 & 37.5 & 7.65 & 14.3 & 25.4 \\
\hline Alfalfa & 8.497 & 54.744 & 0.080 & - & - & 42.153 & 45.1 & 53.3 & 61.4 & 13.8 & 21.3 & 42.6 \\
\hline \multicolumn{13}{|c|}{ Organic matter } \\
\hline Jiggs & 6.987 & 49.962 & 0.052 & - & _ & 32.458 & 44.6 & 51.5 & 58.4 & 26.9 & 42.6 & _ \\
\hline Tifton-85 & 2.254 & 61.685 & 0.046 & _- & _ & 31.778 & 50.8 & 58.1 & 65.5 & 33.7 & 51.5 & _- \\
\hline Stylo & 7.192 & 38.015 & 0.047 & _ & - & 25.592 & 29.9 & 36.9 & 43.8 & 14.1 & 32.3 & 70.1 \\
\hline Alfalfa & 6.498 & 55.477 & 0.070 & _- & - & 38.936 & 51.5 & 58.4 & 65.3 & 23.6 & 38.8 & - \\
\hline \multicolumn{13}{|c|}{ Neutral Detergent Fiber } \\
\hline Jiggs & - & 45.000 & 0.043 & 47.225 & 3.409 & - & 44.8 & 53.8 & 62.7 & 44.2 & _ & _ \\
\hline Tifton-85 & - & 40.000 & 0.042 & 38.509 & 11.678 & _ & 54.8 & 64.4 & 74.1 & 54.0 & _ & - \\
\hline
\end{tabular}




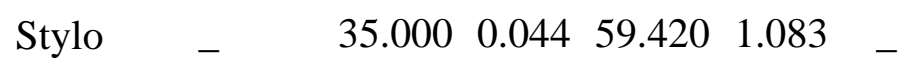

$A$, fraction soluble in water at time zero; $b$, fraction insoluble in water but potentially degradable; $K d$, rate of degradation of the potentially degradable fraction (b); $I$, indigestible fiber fraction; lag, lag time; $E D$, effective degradability; $L L$, lower limit; $U L$, upper limit.
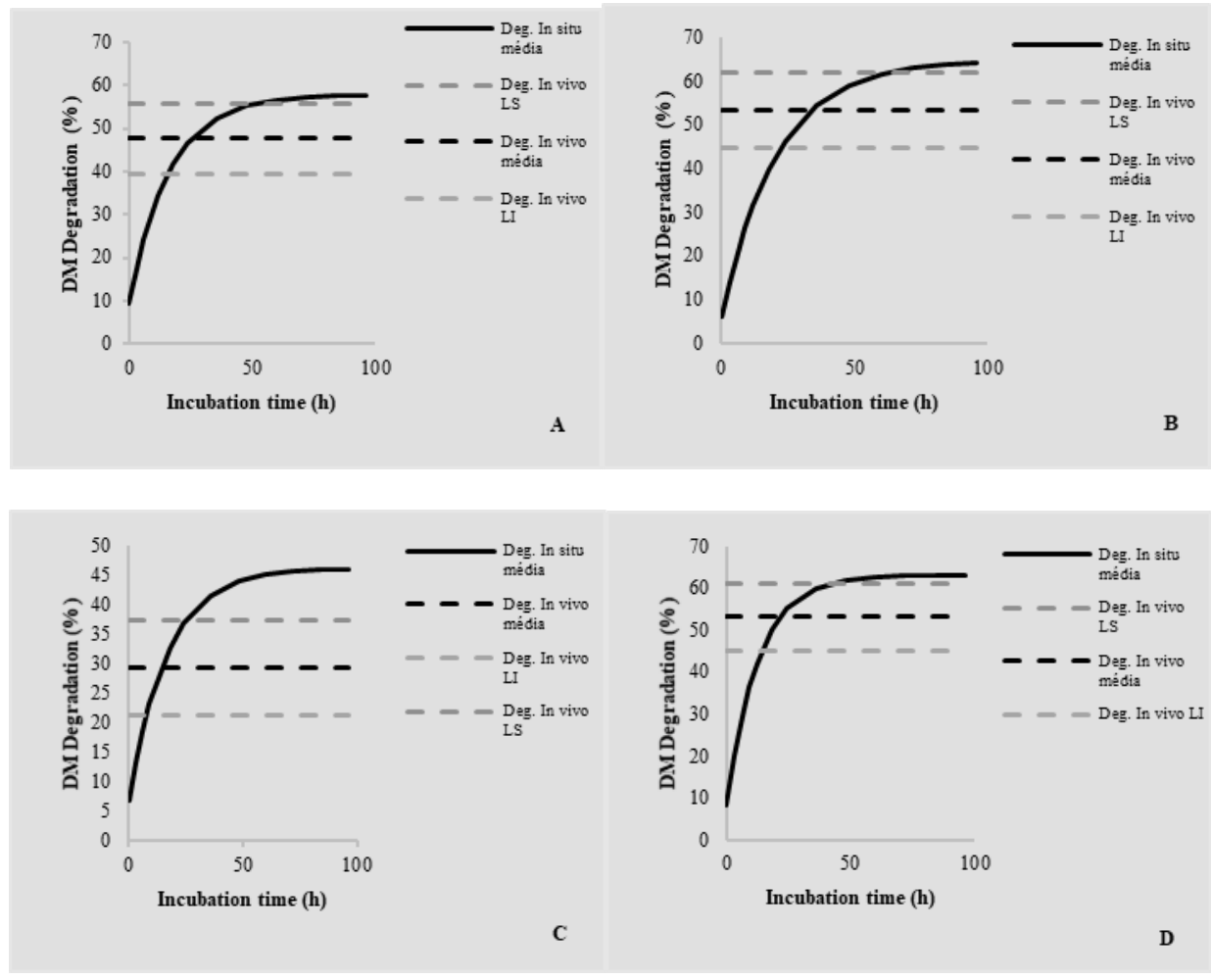

Figure 1. DM degradability obtained in situ vs. DM digestibility obtained in vivo from the Jiggs, Tifton-85, and Alfalfa Hays; LL: lower limit; UL: upper limit

The in vivo OM digestibility of $51.5 \%$ was identical to that obtained by the in situ method after $26.8 \mathrm{~h}$ (Figure 2a). For Tifton-85, stylo and alfalfa hays, the in vivo OM digestibility was equivalent to the in situ $\mathrm{OM}$ degradability, with average value of 58.1, 36.7, and 58.4\%, after $33.7 \mathrm{~h}$ (Figure $2 \mathrm{~b}$ ), in the range of 19.5 to $70.1 \mathrm{~h}$ (Figure $2 \mathrm{c}$ ), and in the interval from $23.6 \mathrm{~h}$ (Figure 2d), respectively. The degradation of OM ranged from 33.7 to $70.1 \mathrm{~h}$ for all types of hay. Except for the stylo, a greater extension of OM degradation occurred in the period from 33.7. 

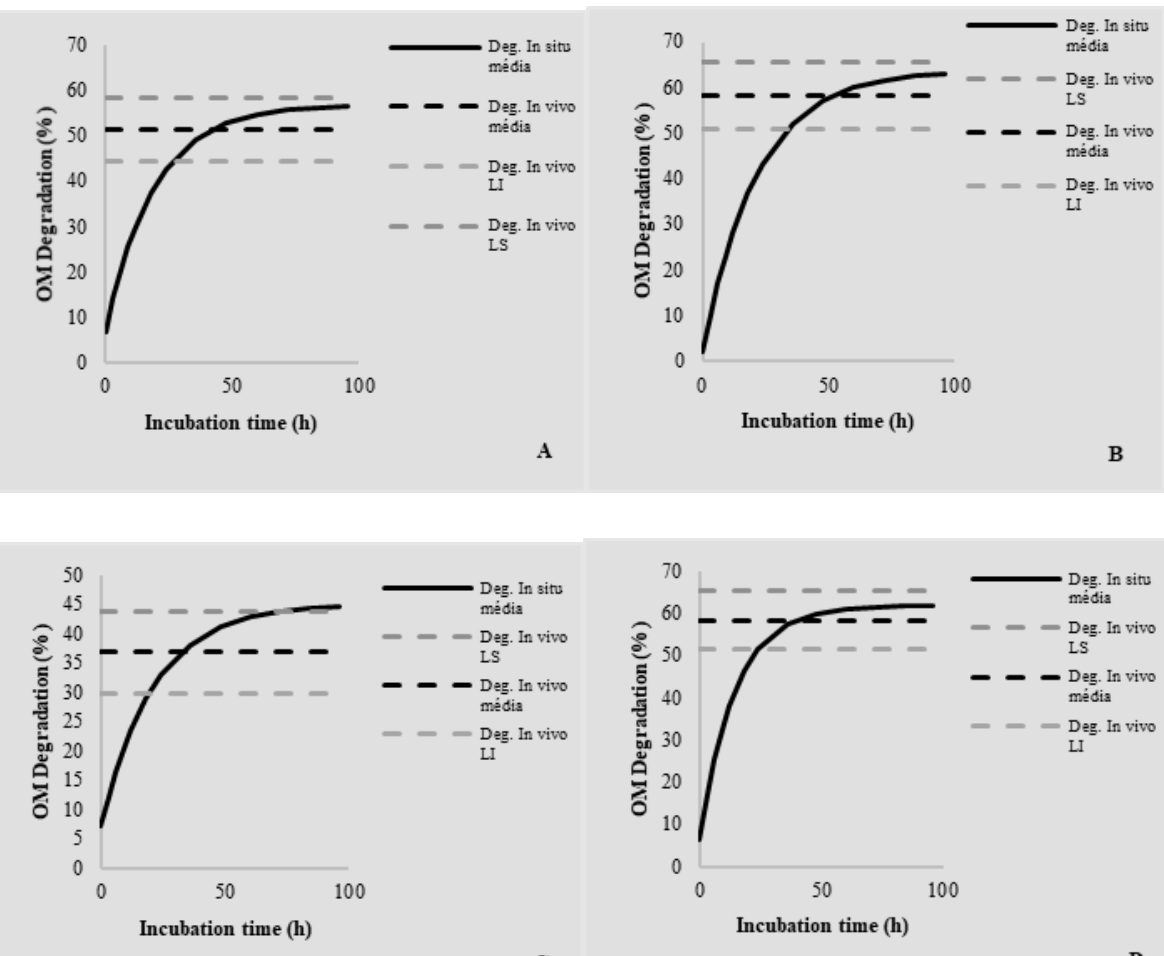

C

D

Figure 2. OM degradability obtained in situ vs. OM digestibility obtained in vivo from the Jiggs, Tifton-85, and Alfalfa Hays; LL: lower limit; UL: upper limit

For Jiggs, Tifton-85, stylo, and alfalfa hays, the in vivo NDFap digestibility (53.7, 64.4, 42.2, and 56.2\%) was equivalent to the in situ method from $44.1 \mathrm{~h}$ (Figure 3a), $54.2 \mathrm{~h}$ (Figure 3b), $37.3 \mathrm{~h}$ (Figure 3c), and $49.9 \mathrm{~h}$ of degradation (Figure 3d), respectively.
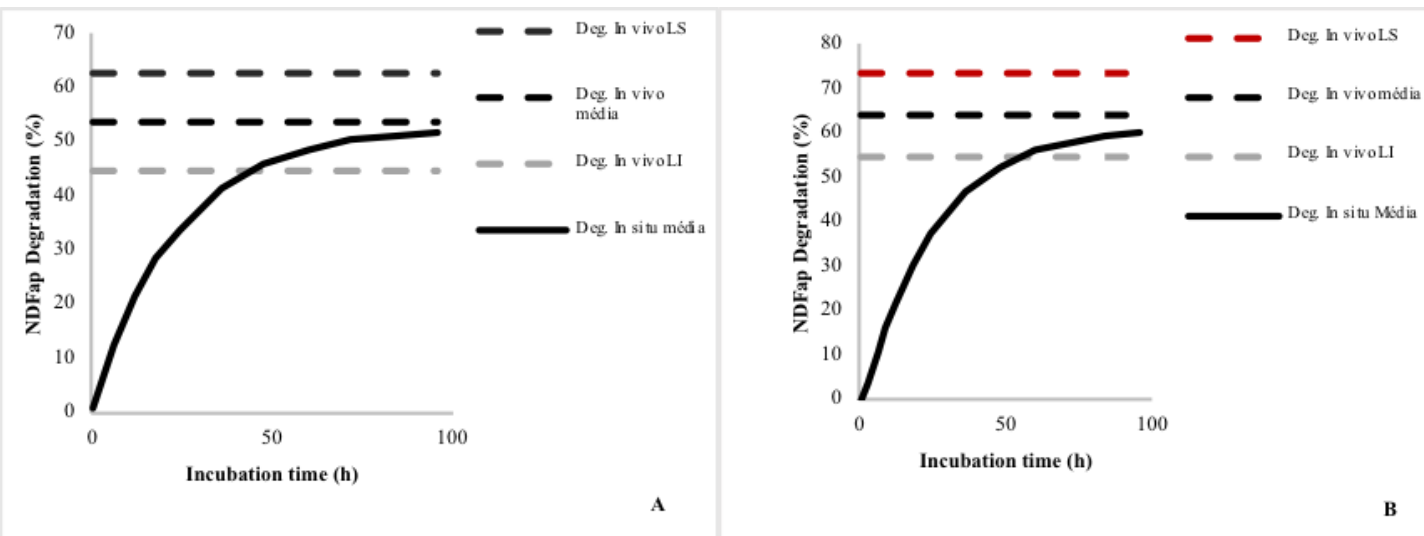


\section{Macrothink}
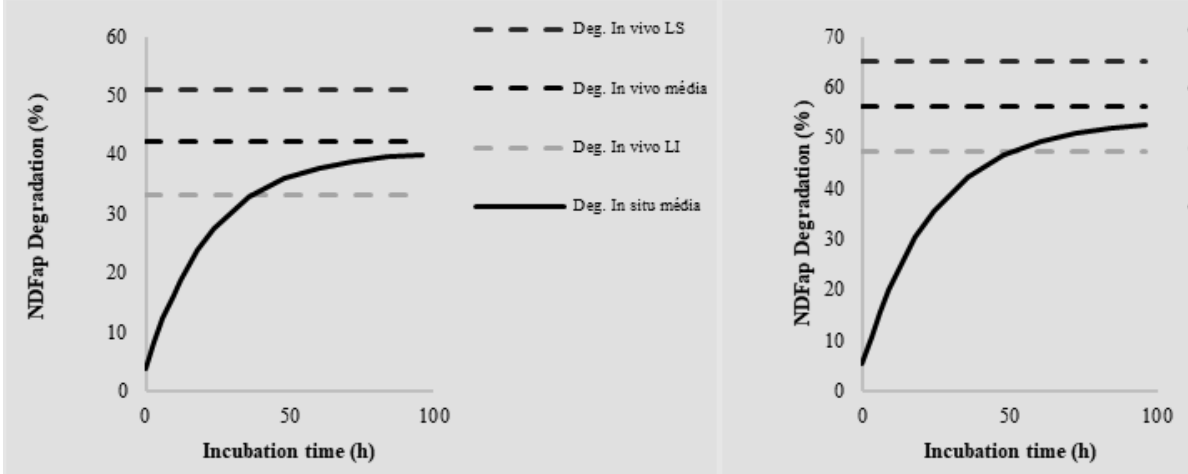

$-\ldots$ Dag. In vivo LS

C

Figure 3. NDFap degradability obtained in situ vs. NDFap digestibility obtained in vivo from the Jiggs, Tifton-85, and Alfalfa Hays; LL: lower limit; UL: upper limit

\section{Discussion}

For sheep, with an average live weight of $35 \mathrm{~kg}$ and on forage-based diets, NRC (2007) recommends a DM intake of $1090 \mathrm{~g} /$ day and TDN intake of $720 \mathrm{~g} \mathrm{day}^{-1}$. In our study, only alfalfa hay met the requirement of DM intake (1 $\left.116 \mathrm{~g} \mathrm{day}^{-1}\right)$, while TDN intake (662 $\left.\mathrm{g} \mathrm{day}^{-1}\right)$ accounted for $91.9 \%$ of the recommended value for this animal category.

The potential for forage intake is negatively related to iNDF content. Rumen filling of animals fed roughage with high iNDF content favors a longer feed retention time in the rumen, reflecting a lower DM intake. Thus, the lowest DM intake obtained in our study when using stylo hay in sheep diet can be attributed to its high levels of NDF and lignin and the high iNDF/NDFap ratio (Tables 1 and 2).

The low CP intake $(P<0.05)$ of animals fed stylo hay in our study (Table 2$)$ can be attributed to its low protein content $(6.30 \% \mathrm{CP})$, possibly due to the more advanced stage of maturity of the plant on the occasion of the harvest and/or the loss of leaves during the dehydration process of the forage in the field. Leaf losses during hay production are frequent and generally higher in legumes than in grasses.

The negative nitrogen balance for the animals that consumed stylo hay indicated that $\mathrm{CP}$ intake did not meet the animal nutrition requirements (Table 2). Silva et al. (2018) also found that for sheep, there was a negative nitrogen balance for diet with stylo silage without concentrate compared with stylo silage with concentrate and corn silage with concentrate due to lower $\mathrm{N}$ ingestion and absorption.

The deficiency in protein intake of the animals that ingested stylo hay possibly compromised the digestibility of this nutrient. Dietary protein deficiency limits ruminal activity, affecting nutrient intake and digestibility, and consequently, animal performance (Machado et al., 2011). Excluding stylo hay, the other hays used in sheep diets presented better digestibility, possibly because they met the minimum protein requirement.

The higher NDF digestibility of alfalfa hay, when compared with stylo hay, may be related to the higher DM intake of alfalfa hay because, according to Sun et al. (2012), high degradation 
rates imply increased DM intake and performance.

According to Kammes et al. (2012), the rate of passage from the rumen generally increases with increased intake. Kammes and Allen (2012) verified faster rates of passage and digestion of small particles for alfalfa compared with orchard grass silage. According to these authors, the composition of the rumen mat and its effect on particle passage is likely a balance between the rates of passage, digestion, and reduction. In addition to the size, the shape of particles within the rumen mat is probably important, wherein cuboidal-shaped fragments of legumes usually pass from the rumen faster than grass particles, which are elongated and needle-like (Buxton et al., 1996).

The values found for the degradation of Jiggs, Tifton-85, and alfalfa hays were within the range recommended for high-quality fodder. In the present study, the adoption of a greater number of incubation times was justified to obtain a confidence interval for the substitution of one method for the other. The low value found for DM degradability for stylo hay may be negatively related to high levels of NDFap, ADF, and lignin (Table 1), which are cell-wall components that express direct responses in digestibility.

Alfalfa hay provides a higher nutrient intake than other hays. The alfalfa and bermuda grass hays used in sheep diets presented better digestibility than stylo hay. The results are suitable to predict in vivo digestibility from in situ degradability parameters.

\section{References}

Benninghoff, J., Paschke-Beese, M., \& Südekum, K. H. (2015). In situ and in vitro ruminal degradation of maize grain and untreated or xylose-treated wheat, barley and rye grains. Animal Feed Science and Technology, 210, 86-93. https://doi.org/10.1016/j.anifeedsci.2015.10.002

Buxton, D. R., Mertens, D. R., \& Fisher, D. S. (1996). Forage quality and ruminant utilization. In L. E. Moser, D. R. Buxton, \& M. D. Casler (Eds.), Cool-Season Forage Grasses (pp. 229-266). Madison: American Society of Agronomy. https://doi.org/10.2134/agronmonogr34.c8

Chaudhry, A. S., \& Mohamed, R. A. I. (2011). Using fistulated sheep to compare in sacco and in vitro rumen degradation of selected feeds. Animal Production Science, 51, 1015-1024. https://doi.org/10.1071/AN10273

Detmann, E., Souza, M. A., Valadares Filho, S. C., Queiroz, A. C., Berchielli, T. T., Saliba, E. O. S., ... Azevedo, J. A. G. (2012). Métodos para Análise de Alimentos - INCT - Ciência Animal. Visconde do Rio Branco: Suprema.

Di Marco, O. N., Ressia, M. A., Arias, S., Aello, M. S., \& Arzadún, M. (2009). Digestibility of forage silages from grain, sweet and bmr sorghum types: Comparison of in vivo in situ and in vitro data. Animal Feed Science and Technology, 153, 161-168. https://doi.org/10.1016/j.anifeedsci.2009.06.003

Hall, M. B., Hoover, W. H., \& Jennings, J. P. (1999). A method for partitioning neutral detergent soluble carbohydrates. Journal of the Science of Food and Agriculture, 79, 2079-2086.https://doi.org/10.1002/(SICI)1097-0010(199912)79:15<2079::AID-JSFA502>3.0 . $\mathrm{CO} ; 2-\mathrm{Z}$ 
Kammes, K. L., \& Allen, M. S. (2012). Rates of particle size reduction and passage are faster for legume compared with cool-season grass, resulting in lower rumen fill and less effective fiber. Journal of Dairy Science, 95, 3288-3297. https://doi.org/10.3168/jds.2011-5022

Kammes, K. L., Ying, Y., Allen, \& M. S. (2012). Nutrient demand interacts with legume particle length to affect digestion responses and rumen pool sizes in dairy cows. Journal of Dairy Science, 95, 2616-2631. https://doi.org/10.3168/jds.2011-4906

Krizsan, S. J., Jancik, F., Ramin, M., \& Huhtanen, P. (2013). Comparison of some aspects of the in situ and in vitro methods in evaluation of neutral detergent fiber digestion. Journal of Animal Science, 91, 838-847. https://doi.org/10.2527/jas.2012-5343

Machado, P. A. S., Valadares Filho, S. C., Valadares, R. F. D., Paulino, M. F., Pina, D. S., \& Paixão, M. L. (2011). Parâmetros nutricionais e produtivos em bovinos de corte a pasto alimentados com diferentes quantidades de suplemento. Revista Brasileira de Zootecnia, 40, 1303-1312. https://doi.org/10.1590/S1516-35982011000600020

Mehrez, A. Z., \& Ørskov, E. R. (1977). A study of the artificial fiber bag technique for determining the digestibility of feeds in the rumen. Journal of Agricultural Science, 88, 645-650. https://doi.org/10.1017/S0021859600037321

Mertens, D. R., \& Loften, J. R. (1980). The effect of starch on forage fiber digestion kinetics in vitro. Journal of Dairy Science, 63, 1437-1446. https://doi.org/0.3168/jds.S0022-0302(80)83101-8

National Research Council - NRC. (2007). Nutrient requirements of small ruminants: sheep, goats, cervids, and New World camelids. Washington D.C.: National Academy of Science. p. 362.

Olivo, P. M., Santos, G. T., Ítavo, L. C. V., Silva Junior, R. C., Leal, E. S., \& Prado, R. M. (2017). Assessing the nutritional value of agroindustrial co-products and feed through chemical composition, in vitro digestibility, and gas production technique. Acta Scientiarum Animal Science, 39, 289-295. https://doi.org/10.4025/actascianimsci.v39i3.34024

Ørskov, E. R., \& McDonald, I. (1979). The estimation of protein degradability in the rumen from incubation measurements weighted according to rate of passage. The Journal of Agricultural Science, 92, 449-453. https://doi.org/10.1017/S0021859600063048

Silva, J. S., Ribeiro, K. G., Pereira, O. G., Mantovani, H. C., Cecon, P. R., Pereira, R. C., \& Silva, J. L. (2018). Nutritive value and fermentation quality of palisade grass and stylo mixed silages. Animal Science Journal, 72, 72-78. https://doi.org/10.1111/asj.12854

Sniffen, C. J., O’Connor, J. D., Van Soest, P. J., Fox, D. G., \& Russell, J. B. (1992). A net carbohydrate and protein system for evaluating cattle diets: II. Carbohydrate and protein $\begin{array}{lllll}\text { availability. Journal of Animal } & \text { Science, } & 70, & \text { 3562-3577. }\end{array}$ https://doi.org/10.2527/1992.70113562x

Sun, X. Z., Waghorn, G. C., \& Clark, H. (2010). Cultivar and age of regrowth effects on physical, chemical and in sacco degradation kinetics of vegetative perennial ryegrass (Lolium perenne L.). Animal Feed Science and Technology, 155, 172-185. https://doi.org/10.1016/j.anifeedsci.2009.12.004

Valente, T. N. P., Detmann, E., Valadares Filho, S. C., Cunha, M., Queiroz, A. C., \& Sampaio, C. B. (2011). In situ estimation of indigestible compounds contents in cattle feed and feces 
using bags made from different textiles. Revista Brasileira de Zootecnia, 40, 666-675. https://doi.org/10.1590/S1516-35982011000300027

Weiss, W. P., Conrad, H. R., \& Pierre, N. R. S. (1992). A theoretically-based model for predicting total digestible nutrient values of forages and concentrates. Animal Feed Science and Technology, 39, 95-110. https://doi.org/10.1016/0377-8401(92)90034-4

\section{Copyright Disclaimer}

Copyright for this article is retained by the author(s), with first publication rights granted to the journal.

This is an open-access article distributed under the terms and conditions of the Creative Commons Attribution license (http://creativecommons.org/licenses/by/4.0/). 